University of New Hampshire

University of New Hampshire Scholars' Repository

Master's Theses and Capstones

Student Scholarship

Spring 2020

\title{
A Spatial Life Cycle Cost Comparison of Residential Greywater and Rainwater Harvesting Systems
}

Rebecca Maskwa

University of New Hampshire, Durham

Follow this and additional works at: https://scholars.unh.edu/thesis

\section{Recommended Citation}

Maskwa, Rebecca, "A Spatial Life Cycle Cost Comparison of Residential Greywater and Rainwater Harvesting Systems" (2020). Master's Theses and Capstones. 1344.

https://scholars.unh.edu/thesis/1344

This Thesis is brought to you for free and open access by the Student Scholarship at University of New Hampshire Scholars' Repository. It has been accepted for inclusion in Master's Theses and Capstones by an authorized administrator of University of New Hampshire Scholars' Repository. For more information, please contact Scholarly.Communication@unh.edu. 
A Spatial Life Cycle Cost Comparison of Residential Greywater and Rainwater Harvesting Systems

\author{
By \\ Rebecca Maskwa \\ B.S. in Civil and Environmental Engineering, College of Engineering and Physical Sciences \\ College, 2016
}

\title{
THESIS
}
Submitted to the University of New Hampshire
in Partial Fulfillment of
the Requirements for the Degree of
Master of Science
in

Civil and Environmental Engineering

May, 2020 
This thesis was examined and approved in partial fulfillment of the requirements for the degree of Master of Science in Civil and Environmental Engineering by:

Dissertation Director, Dr. Weiwei Mo, Assistant Professor, Department of Civil and Environmental Engineering, University of New Hampshire

Dr. Kevin Gardner, Professor, Department of Civil and Environmental Engineering, University of New Hampshire and University of Louisville

Dr. Kyle Kwiatkowski, Assistant Professor, Department of Civil and Environmental Engineering, University of New Hampshire

On April 9, 2020

Approval signatures are on file with the University of New Hampshire Graduate School. 


\section{Table of Contents}

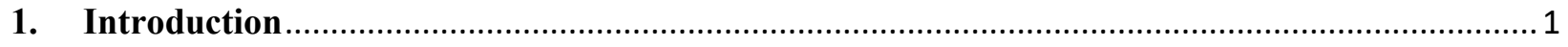

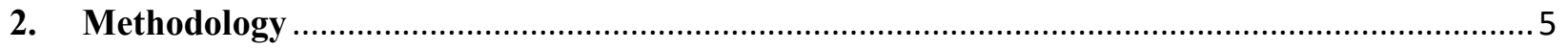

2.1 System Dynamics Modeling of the RWH and GWR Systems ..................................................... 5

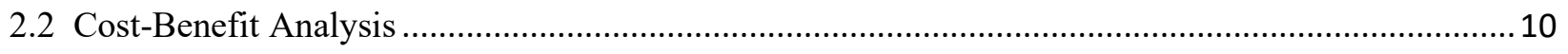

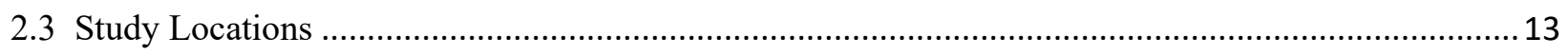

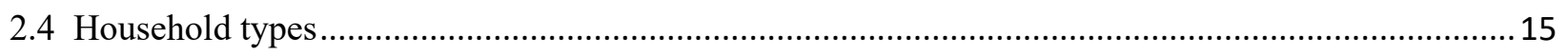

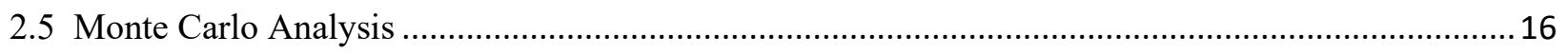

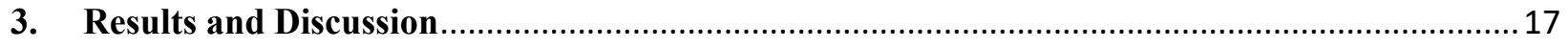

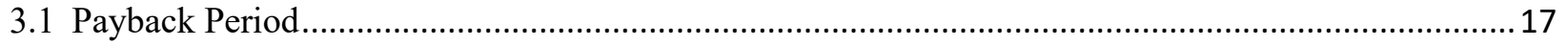

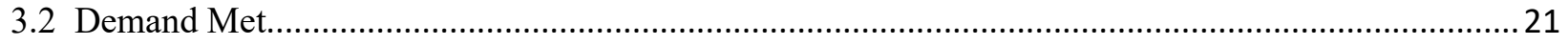

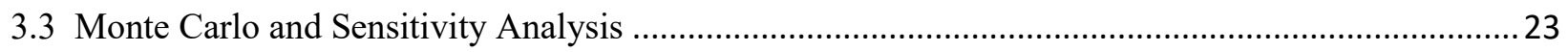

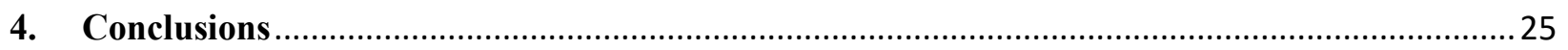

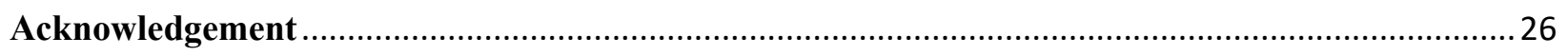

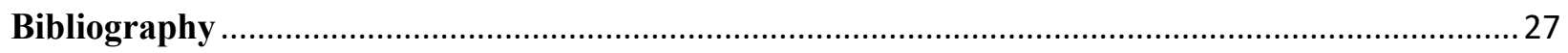




\begin{abstract}
With populations rising and increased urbanization, water stress and water shortage have become more common in cities across the US. Incorporating decentralized water systems into today's largely centralized water systems has been considered as a potential means to reduce a family's residential water footprint and provide an economic benefit over time. However, our understanding regarding how different decentralized water systems compare to each other when installed in different types of buildings under different geospatial and climate conditions remain limited. This study considers implementing greywater recycling (GWR) and rainwater harvesting (RWH) systems in two different household sizes in 12 different cities within the United States. Each city has different characteristics to consider, such as precipitation dynamics, irrigation periods, and utility rates. This investigation calculates the percent of water that meets the demand of a household and the total economic savings/payback time as a function of tank size to achieve the optimum benefit of each system type using a systems dynamics model with a daily time step. We found that for GWR, cities had optimum tank sizes of 2-3 $\mathrm{m}^{3}$ for multi-family housing and 0.75- $0.85 \mathrm{~m}^{3}$ for single-family housing. Demand met for GWR ranged from $70-90 \%$, while RWH ranged from 50-70\% across all cities. Optimal tank sizes for RWH ranged from 5-10 $\mathrm{m}^{3}$ for multi-family housing and 4-6 $\mathrm{m}^{3}$ for single-family housing. Overall, Boston, Seattle, and Atlanta performed the best for both GWR and RWH, single-family and multi-family, in terms of payback and demand met.
\end{abstract}




\section{Introduction}

Globally, water resources are being stressed due to increasing water demand driven by population growth, urbanization, and industrialization (WWC, 2014). Almost 700 million people suffer from water scarcity currently and by 2050 it will increase to 2.5 billion (Hameeteman et al., 2013; UNDP, 2006). Research related to the U.S. shows that future water supply in some regions are likely to be affected by severe water shortages (Brown et al., 2019). Lifestyle changes and new technologies, such as taking fewer showers or installing water efficient appliances, are being suggested and developed to help alleviate the overall water shortage globally (Das et al., 2015; SOW, 2018). One type of technology that has been increasingly discussed is household decentralized water systems, such as rainwater harvesting or greywater recycling systems (EPA, 2016). Decentralized water systems have the potential to provide many benefits to a community, especially the ability to alleviate water stress in the centralized water systems, improve system sustainability and resiliency, and increase water availability (EPA, 2016). Many researchers are looking to understand how decentralized water systems work and the true benefits that they provide (Mankad \& Tapsuwan, 2011).

Greywater recycling (GWR) is water that has been used once by the consumer, treated, and then used again for another purpose (Ilemobade et al., 2013; Jefferson et al., 2000). Guidelines for GWR are proposed for both restricted and unrestricted use, which are determined by the water quality requirements. However, these guidelines vary between technologies and individual states (Li et al., 2009). Typical uses of greywater include toilet flushing and irrigation of ornamental plants and grasses (Maeda et al., 1996; Nolde, 2000; Valentina Lazarova, Takashi Asano, 2013). The water that is reused for this purpose comes from sources such as the shower, bathroom sink, 
or the washing machine (Eriksson, 2002; Jefferson et al., 2000; Otterpohl et al., 1999).

Greywater often contains additional nutrients that have a positive influence on irrigation. GWR systems can be separated in two different categories: diversion systems and filtration/purification systems (E. Friedler, 2008). Diversion systems are integrated as permanent piping within the original plumbing network of a building and primarily used for irrigation. This system type does not require additional treatment since the storage time can be less than a few hours (E. Friedler, 2008). Purification/filtration systems include treatment of the greywater before being redistributed for reuse for either potable or near-potable uses (E. Friedler, 2008; Li et al., 2009). Many different treatment processes have been considered including membrane filtration, sand filtration and disinfection in combination, coagulation and granular activated carbon sorption in combination, and membrane bioreactor (Li et al., 2009).

Rainwater harvesting (RWH) is another type of technology that aims to reduce water stress from centralized drinking water services (Campisano et al., 2017; GhaffarianHoseini et al., 2016; Hamel \& Fletcher, 2014). Conventional RWH systems capture stormwater runoff from impervious cover for both potable and non-potable uses (Siegel, 2015). The catchment area type and end-use outlets determine the level of treatment needed. Rooftop collection can be suitable for both irrigation, outdoor cleaning activities, laundry, and toilet flushing and requires simple filtration for removal of general debris and disinfection (Campisano et al., 2017; CTCN, 2018; Despins et al., 2009). Ground-surface collection may have a higher loss of water due to infiltration and may require more advanced treatment because of contamination from cars and other pollutants (CTCN, 2018). New RWH designs are continuously being developed with ideas 
of collapsible tanks and lower-energy processes (Abbasi \& Abbasi, 2011; Campisano et al., 2017).

GWR and RWH technologies can be utilized and implemented on a residential scale, both for detached homes and apartment style living. They can theoretically help improve potable water resource availability and reliability with their capability and adaptability of storing, reducing, and/or reusing reclaimed water for non-potable domestic use (Campisano et al., 2017). These systems also improve water source diversification, extend internal water usage, and enable a more efficient resource use (Leigh \& Lee, 2019). However, such benefits vary geographically depending on local climate, water supply and use, and socioeconomic conditions. The initial costs as well as uncertainties about the return of investment have often been cited as barriers to broader adoption of RWH and GWR systems (Fewtrell \& Kay, 2007; NESC, 2000). It is therefore important to understand the economic and other performance measures of RWH and GWR systems considering different geospatial contexts.

Many studies have investigated RWH or GWR systems on an individual basis. Payback time, economic savings, water saving, and stormwater reduction are commonly used to evaluate these systems. Table 1 provides a list of such studies with their study contexts and reported outcomes. These studies had reported a wide range of RWH or GWR's economic performances, ranging from not feasible at all to a relatively short payback time of less than 10 years. This could be a result of varying site-specific characteristics, such as local climate, system design, household water demand, and greywater generation (Hashim et al., 2013). Hence, it is difficult to compare the reported outcomes across the previous studies. Only a small number of studies compared 
both types of technologies (Marinoski et al., 2018; Morales-Pinzón et al., 2015; Willuweit \& O’Sullivan, 2013), but most of the studies only used them in a capacity to compare simulation modeling programs instead of comparing their environmental or economic benefits/costs (Morales-Pinzón et al., 2015; Willuweit \& O’Sullivan, 2013). Morales-Pinzón et al. (2015) anticipated that in the future an expansion of their analysis will involve a more integrated look at the results comparing RWH and GWR. Marinoski et al. (2018) found that in residental housholds consisting of three people in southern Brazil, RWH had a potential water saving of 3,500 liters per month, while GWR had a potential to save 2,400 liters per month. However, these studies focused on individual case applications, while the influence of spatial context on systems' performance was not discussed. Location is a significant characteristic when discussing environmental benefits and economic potential because it dictates the climate, precipitation, and economic restrictions within the location in question (Wang \& Zimmerman, 2015). Only three studies were able to incorporate spatial variations and dynamic modeling within their research, but they lacked applicability to varying scales of building composition (Memon et al., 2005; Mwenge Kahinda et al., 2009; Wang \& Zimmerman, 2015). Previous studies seldom included analyses pertaining to both economic and environmental benefits of GWR or RWH to allow comparison between the two.

Table 1 Condensed literature review summary highlighting payback time, technology investigated, and whether the technology resulted in water savings.

\begin{tabular}{|ccccccc|}
\hline Source & System type & $\begin{array}{c}\text { Payback time } \\
\text { (years) }\end{array}$ & $\begin{array}{c}\text { Water saving } \\
\text { considered? } \\
\text { (Y/N) }\end{array}$ & Water uses & $\begin{array}{c}\text { Household } \\
\text { type }\end{array}$ & Location \\
\hline $\begin{array}{c}\text { Friedler, E. } \\
\text { (2005) }\end{array}$ & GWR & $7-14$ & $\begin{array}{c}\text { System } \\
\text { dependent }\end{array}$ & Toilet & Multi-family & Israel \\
\hline $\begin{array}{c}\text { Ilemobade, } \\
\text { AA. (2013) }\end{array}$ & GWR & Unfeasible & $\mathrm{N}$ & Toilet & Multi-family & South Africa \\
\hline
\end{tabular}




\begin{tabular}{|c|c|c|c|c|c|c|}
\hline $\begin{array}{c}\text { (Jeong et al., } \\
2018)\end{array}$ & GWR & $\begin{array}{c}\text { System } \\
\text { dependent }\end{array}$ & $\mathrm{Y}$ & $\begin{array}{l}\text { Toilet and } \\
\text { irrigation }\end{array}$ & Single-family & Atlanta, GA \\
\hline $\begin{array}{c}\text { Memon,F.A. } \\
(2005)\end{array}$ & GWR & $\begin{array}{c}\text { Utility price } \\
\text { dependent }\end{array}$ & $\mathrm{Y}$ & Toilet & Multi-family & UK \\
\hline Lam,C. (2017) & GWR & Not provided & $\mathrm{N}$ & Toilet & Multi-family & Hong Kong \\
\hline Wang (2015) & RWH & $\begin{array}{l}\text { Unfeasible in } \\
\text { cities with low } \\
\text { utility costs }\end{array}$ & $\mathrm{N}$ & Not specified & Commercial & $\begin{array}{c}\text { Various U.S } \\
\text { cities }\end{array}$ \\
\hline $\begin{array}{c}\text { Vialle,C. } \\
\text { (2011) }\end{array}$ & RWH & Not provided & $\mathrm{N}$ & Toilet & Single-family & France \\
\hline $\begin{array}{c}\text { Ward, S. } \\
\text { (2012) }\end{array}$ & RWH & $6-11$ & $\mathrm{Y}$ & Toilet & Commercial & UK \\
\hline $\begin{array}{c}\text { Way, C. } \\
(2010)\end{array}$ & RWH & Not provided & $\mathrm{N}$ & Not specified & Single-family & UK \\
\hline $\begin{array}{l}\text { Ward, S. } \\
(2010)\end{array}$ & RWH & $14-22$ & $\mathrm{~N}$ & Toilet & $\begin{array}{l}\text { Single-family } \\
\text { and } \\
\text { commercial }\end{array}$ & UK \\
\hline $\begin{array}{c}\text { Morales- } \\
\text { Pinzón,T. } \\
\text { (2015) }\end{array}$ & RWH & $\begin{array}{l}\text { Utility price } \\
\text { dependent }\end{array}$ & $\mathrm{N}$ & $\begin{array}{l}\text { Toilet, } \\
\text { irrigation, and } \\
\text { laundry }\end{array}$ & $\begin{array}{l}\text { Single-family } \\
\text { and multi- } \\
\text { family }\end{array}$ & Spain \\
\hline $\begin{array}{c}\text { Mwenge } \\
\text { Kahinda,J. } \\
(\mathbf{2 0 0 9 )}\end{array}$ & RWH & Not provided & $\mathrm{N}$ & Soil recharge & Commercial & South Africa \\
\hline $\begin{array}{l}\text { Domènech,L. } \\
\text { (2011) }\end{array}$ & RWH & $60-80$ & $\begin{array}{c}\mathrm{Y} \\
\text { (45\% demand } \\
\text { met) }\end{array}$ & $\begin{array}{l}\text { Toilet and } \\
\text { irrigation }\end{array}$ & $\begin{array}{l}\text { Single-family } \\
\text { and multi- } \\
\text { family }\end{array}$ & Spain \\
\hline $\begin{array}{c}\text { Hashim,H. } \\
\text { (2013) }\end{array}$ & RWH & 25 & $\mathrm{Y}$ & $\begin{array}{l}\text { Toilet and } \\
\text { irrigation }\end{array}$ & Single-family & Malaysia \\
\hline
\end{tabular}

\section{Error! Reference source not found.}

Accordingly, this study captured and compared RWH and GWR systems applied to a typical single family and a typical multi-family house through system dynamics modeling and life cycle cost assessment. The goal is to understand how specific precipitation patterns and other geographic-specific parameters influence the economic and environmental benefits of GWR and RWH decentralized systems.

\section{Methodology}

\subsection{System Dynamics Modeling of the RWH and GWR Systems}

The system dynamics models (SDMs) for RWH and GWR were developed using the Vensim ${ }^{\circledR}$ software. System dynamics modeling is a technique used to mimic changes in system status over time (Ford, 2010). They utilize stocks, flows, auxiliary variables, and connectors to show how 
different variables within a system interact with one another and how the system reacts when one or more variables change. Stocks represent changes of system levels over time (e.g. GWR or RWH tanks). Flows represent the additions to and subtractions from the stock (e.g. rainwater and greywater inflows, yield, or water being spilled out of the tank). Auxiliary variables can influence the system in both internal and external capacities. Connectors visually show how all the auxiliary variables, stocks, and flows are interconnected and how they influence each other (Song \& Mo, 2019). The SDMs developed in this study simulate RWH and GWR systems using ten years of precipitation data (Silva et al., 2015), on a daily time step for both a typical singlefamily and a typical multi-family homes.

The GWR model incorporates the average consumer water use rates for bathing, laundry, and handwashing to determine the potential water reclamation capacity for GWR (Figure). The RWH model incorporates the average collection of rainfall based on the typical roof-top size to determine the potential water collection capacity for RWH (Figure). The volume of water collected in the storage tank is then analyzed to determine the yield based on the total nonpotable demand. The total non-potable demand is determined by for the amount of water used for residential irrigation and toilet flushing (Figure). A second part of the model is the simulation of the net economic savings. Inflow of the net economic saving stock was calculated based on the cost savings obtained through reduced use of services from the utilities. Outflows of the net economic saving stock include initial construction, operation, and maintenance of the decentralized systems. Equations that correspond to each of the auxiliary variables, stocks, and flows are described in Section 2.1.1. 


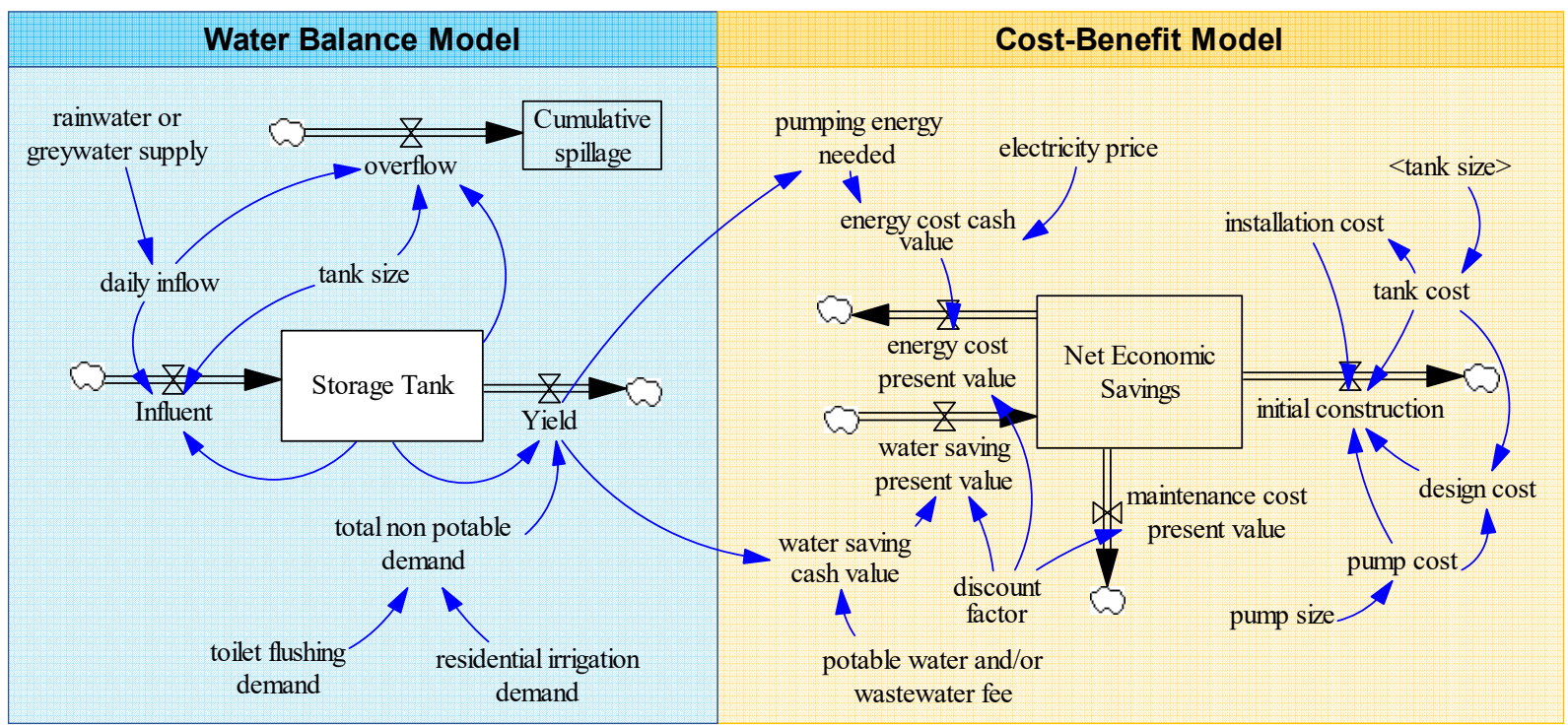

Figure 1 A simplified diagram of the stock and flow components that contribute to the SDM of GWR and RWH. Aspects of the model that are in boxes are stocks, while the arrows valves are flows. Variables without boxes are auxiliary variables, and blue arrows that connect to other auxiliary variables are connectors.

\subsubsection{Demand of Alternative Water Supply}

In this study, we assume rainwater and greywater are being collected for two types of nonpotable uses: lawn irrigation and toilet flushing. The amount of toilet flushing at each household was calculated using Equation 1.

$$
D_{f}=n * V_{f}
$$

Equation 1

where $D_{f}$ is the total toilet flushing demand, $\mathrm{m}^{3} /$ day; $n$ is the number of tenants per household; and $V_{f}$ is the volume of water used for toilet flushing, $0.072 \mathrm{~m}^{3} /$ day/person (USGS, 2016). The amount of water used for lawn irrigation was calculated using Equation 2.

$$
D_{i, t}=\left\{\begin{array}{r}
A * f * E T_{t} / \text { eff }, P_{t}=0, t \in I P \\
0, \text { Otherwise }
\end{array}\right.
$$


where $D_{i, t}$ is the lawn irrigation demand on day $t$ during the irrigation period $I P$ of a given city, $\mathrm{m}^{3} /$ day; We assumed $I P$ is when the average monthly temperature is between 10 and 32 degrees Celsius (Forrester et al., 2018; Goatley Jr., 2015; Lawns, 2018; Murphy, 2001; Waltz \& Landry, 2017). $A$ is the total lawn area of a household, $\mathrm{m}^{2} ; f$ is the plant factor, assumed to be 0.7 , unitless; $E T_{t}$ is the daily evapotranspiration of each city, $\mathrm{m} /$ day, and, eff is the irrigation efficiency, assumed to be 0.75 , unitless, for the rotor sprinkler distribution network (EPA, 2016). The total demand of alternative water supply is calculated as the sum of $D_{f}$ and $D_{i, t}$.

\subsubsection{Simulation of Rainwater and Greywater Inflow}

Rainwater inflow in the RWH model is solely dependent on the amount of rainfall. Equation 3 describes how the initial collected inflow $I_{R W, t}, \mathrm{~m}^{3} /$ day is determined, which is by the amount of rainfall each day $P_{t}, \mathrm{ft} /$ day (NOAA, 2018), the total roof area $A, \mathrm{ft}^{2}$ (NAHB, 2015) and the runoff coefficient $\mu$, associated with the amount of debris that diverts the rainwater away from the collection system, assumed to be 0.8 , unitless (SWRCB, 2011). A conversion factor, $C$, was also applied to convert $\mathrm{ft}^{3}$ to $\mathrm{m}^{3}(0.028)$

$$
I_{R W, t}=P_{t} A \mu C
$$

Equation 3

Greywater inflow in the GWR model was assumed to be water coming from showering, sink, and laundry. The average American uses 80-100 gallons of water per day (USGS, 2016). The breakdown of the residential indoor water consumption has been provided in Figure 2. Overall, around $50-80 \%$ of the water can be utilized for GWR Error! Reference source not found.. Equation 4 represents the collected inflow calculation:

$$
I_{G W, t}=n\left(v_{s h, t}+v_{h w, t}+\left(v_{l, t} n_{l}\right)\right)
$$

Equation 4 
Where $I$ is greywater inflow volume on day $t, \mathrm{~m}^{3} /$ day; $n$ is number of tenants; $v_{s h}$ is volume of water for showering, $0.65 \mathrm{~m}^{3} /$ day/person (HWW, 2018; USGS, 2016); $v_{h w}$ is volume of water from the sink, $0.023 \mathrm{~m}^{3} /$ day/person (HWW, 2018; USGS, 2016); $v_{l}$ is the volume of water used for one load of laundry, $0.057 \mathrm{~m}^{3} /$ day/person (HWW, 2018; USGS, 2016); and $n_{l}$ is the number of loads of laundry per day 0.32 loads/day (HWW, 2018; USGS, 2016).

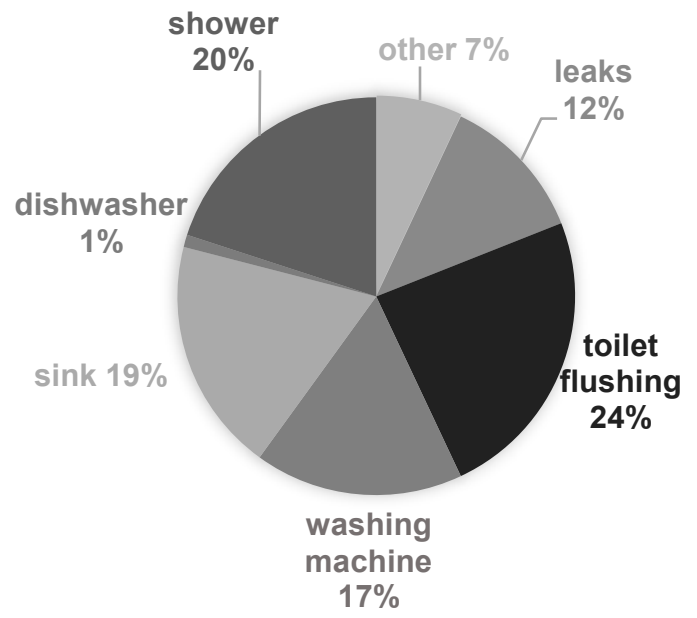

Figure 2. Percentage breakdown for residential indoor water consumption and end uses (HWW, 2018; WRF, 2018)

\subsubsection{Water Balance Simulation}

The method that was implemented for the evaluation of the storage tank dynamics includes a yield-after-spillage behavioral model approach previously developed by Fewkes \& Butler, (2000) and Jenkins, (1978). The amount of rainwater or greywater collected for use is dependent upon whether there is room in the storage tank or not. If there is no room for collection within the storage tank, the excess water is diverted away from the system and was assumed to be spilled onto the ground in the RWH system or deposited to the local sewer network in the GWR system (Equation 5). Yield was defined as the amount of rainwater or greywater used for 
meeting the demand. It was calculated based upon the amount of water remaining in the tank from the previous day and the current day's non-potable demand for the household type (Equation 6). The yield of the system will either meet the non-potable demand or only take what is available based upon what is remaining from the previous day. The amount of water remaining in the tank after the day's use was calculated based on the remaining water in the tank from the previous day and the current day's inflow, spillage, and yield (Equation 7).

$$
\begin{array}{cc}
O_{t}= \begin{cases}V_{t-1}+I_{t}-T & \mid V_{t-1}+I_{t} \geq T \\
0 & \mid V_{t-1}+I_{t}<T\end{cases} & \text { Equation } 5 \\
Y_{t}= \begin{cases}D_{t} & \mid D_{t}<V_{t-1}+I_{t}-O_{t} \\
V_{t-1}+I_{t}-O_{t} & \mid D_{t} \geq V_{t-1}+I_{t}-O_{t}\end{cases} & \text { Equation 6 } \\
V_{t}=V_{t-1}+I_{t}-O_{t}-Y_{t} & \text { Equation } 7
\end{array}
$$

Where $O_{\mathrm{t}}$ is overflow from the tank storage, $\mathrm{m}^{3} /$ day; $I_{t}$ is the inflow of water collected from the current day, $\mathrm{m}^{3} ; V_{t-1}$ is the storage tank volume from the previous day, $\mathrm{m}^{3} ; T$ is the tank storage capacity, $\mathrm{m}^{3} ; Y_{t}$ is total yield for the current day, $\mathrm{m}^{3}$; and $D_{t}$ is the demand for the current day, $\mathrm{m}^{3}$. Percent demand met, \%DM, was calculated by the division between $Y_{t}$ and $D_{t}$ (Equations 8$)$.

$$
\% D M=Y_{t} / D_{t}
$$

Equation 8

\subsection{Cost-Benefit Analysis}

A cost-benefit analysis was integrated into the SDMs. Costs of the two types of systems include capital cost and operation and maintenance cost. For this analysis, a discount rate of $0 \%$ has been selected following the practices adopted by Vítková et al. (2014) and Ward et al. (2012). However, a Monte-Carlo analysis and a sensitivity analysis were conducted to examine the influence of discount rate as well as other factors on the model outcome. Capital costs of the RWH and GWR systems include tank cost, installation cost, and design cost (WRF, 2018). Tank 
cost was calculated using cost curves developed based upon data obtained from various manufacturing companies for estimating the cost of the different sized tanks (Rain Harvest Systems, 2017; Supplies, 2017; WRF, 2018). Equation 9 represents the sizing and Equation 10 represents the costing curves that were used for both GWR and RWH in this study. Pump size and pump cost were determined through utilization of WERF LID tool (WRF, 2018). The system installation cost was assumed to be $60 \%$ of the tank cost and the design cost was assumed to be $8 \%$ of the tank and pump cost (WRF, 2018).

$$
\begin{array}{cc}
h p=(Q * F * \rho * 9.8) *(\mathrm{~h} / 2) *(0.00134 / E) & \text { Equation } 9 \\
C_{\text {pump }}=-100.71 h p^{2}+1327.7 * h p-39.38 & \text { Equation } 10
\end{array}
$$

Where $h p$ is the pump horsepower, hp; $Q$ is water flow rate, $0.00025 \mathrm{~m}^{3} / \mathrm{s} ; F$ is the number of fixtures, 1.5 for single-family and 7.5 for multi-family; $\rho$ is water density, $1,000 \mathrm{~kg} / \mathrm{m}^{3} ; h$ is building height, $5 \mathrm{~m}$; $E$ is pump efficiency, assumed to be 0.5 (WRF, 2018); and $C_{\text {pump }}$ is the pump cost, \$.

System operation cost was calculated based upon the cost associated with pumping energy for delivering the collected water for toilet flushing. Rainwater and greywater collection as well as water delivery for irrigation were assumed to be gravity fed (EA, 2010; Marteleira \& Niza, 2018; Vieira et al., 2014). Pumping energy $\left(\mathrm{C}_{\mathrm{E}}\right)$ was estimated in Equation 11 by yield of the systems $Y_{t}$, building height, and the indoor use ratio. The indoor use ratio correlates to the percentage of yield used for used for toilet flushing purposes (Equation 12).

$$
\begin{aligned}
C_{E} & =\frac{\left(Y_{t^{*}} h / 2^{* \rho} * \mathrm{R}\right)}{E * C_{k w h}} \\
R & =D_{f} / D_{t}
\end{aligned}
$$


Where $C_{E}$ is pumping energy, $\mathrm{kWh} /$ day; $h$ is building height, $5 \mathrm{~m} ; \rho$ is water density, 1,000 $\mathrm{kg} / \mathrm{m}^{3} ; R$ is indoor use ratio; $E$ is pumping efficiency, $0.5 ; C_{k w h}$ is conversion to $\mathrm{kWh}, 3.6^{*} 10^{-6}$; and $D_{f}$ is the total toilet flushing demand, $\mathrm{m}^{3} /$ day; and $D_{t}$ is the demand for the current day, $\mathrm{m}^{3}$.

System maintenance costs were dependent on the type of system being utilized and the level of treatment needed. For RWH, it was assumed that only simple filtration was necessary for treatment, and annual inspection requirements can be completed by the homeowner. Thus, the system only required an average of $\$ 100 /$ year for maintenance (CTCN, 2018; Fewkes \& Butler, 2000; IWMI, 2018; Rahman et al., 2012). GWR required additional treatment and maintenance. Many previous studies have considered different technologies and their treatment capabilities, and most have agreed that a household size MBR system can achieve sufficient effluent water quality with relatively lower maintenance costs(Campisano et al., 2017; Leong et al., 2017; Lesjean \& Gnirss, 2006; Liu et al., 2005). Therefore, this study considered MBR treatment for the GWR model. The annual maintenance cost for this technology varies greatly between previous studies and an average of the previously reported values, \$200/year was used in this study (EPA, 2016; GWA, n.d.; Marteleira \& Niza, 2018).

Benefits resulted from installing the RWH or GWR system were calculated based upon reductions in drinking water and wastewater fees paid to the city water and wastewater utilities. Particularly, we assume installing RWH system will only result in savings in drinking water fees, while installing GWR system will result in savings in both potable water and wastewater fees. Many of the cities have had inconsistent trends of increases/decreases in fee prices; for this study the most current utility fees were used and remained constant throughout the 10-year period. 
Payback period was used as an indicator of economic savings or cost for the household. It addresses the amount of time that it takes for the initial investment to be paid back. Payback period is identified by simulating the numerical integrations of net economic savings starting at zero and cumulating until then end of the 10-year simulation (Equation 13). Previous studies have identified a wide range of payback periods as acceptable amount of time that yields economic benefits (Campisano et al., 2017). In this study, any payback period that went beyond the life span of the RWH and GWR systems (10 years) was deemed an unreasonable/unfeasible (Campisano et al., 2017; Rahman et al., 2007; Roebuck et al., 2011).

$$
T=\frac{C_{I}}{S_{a}}
$$

Equation 13

Where $T$ is payback time, years; $C_{I}$ is initial cost, $\$$; and $S_{a}$ is average annual savings, $\$$ year over a 10 -year period. The annual savings was calculated by taking the average difference in $\$ /$ year.

\subsection{Study Locations}

Twelve cities distributed across the US were investigated in this study, each with unique environmental and water supply characteristics (Table 2). Ten years (2007-2017) of historical daily precipitation data were used to determine the time and amount of rainwater supply for each city (NOAA, 2018). The average monthly-temperatures were also collected, which determines the lawn irrigation periods for each city (USCD, 2018) (Figure 3Error! Reference source not found.). The average ET values (Table 2) were obtained from the International Water Management Institute (IWMI, 2018) using the coordinates of each city. The Water Sense Water Budget Tool (EPA, 2018) to determine the monthly landscape water requirement (Section B1 of the supporting information). Current water, wastewater, and electricity rates for each city were 
obtained from each cities municipality websites. (Albuquerque, 2016; Boston, 2016; Chicago, 2016; City, 2016; City of Atlanta, 2016; City of New York, 2018; City of San Diego, 2016; City of Seattle, 2017; City of Tampa Florida, 2011; Dallas, 2016; Philadelphia, 2016; Wichita, 2017)

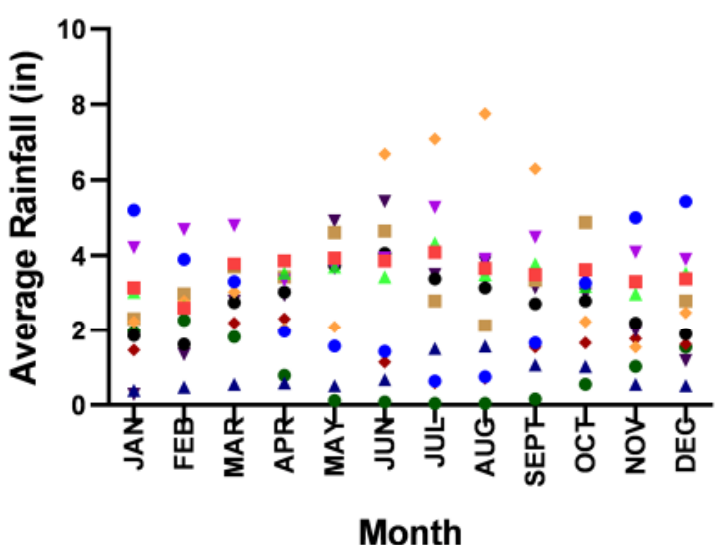

- BOS $=$ NYC $\triangle$ PHIL

- DAL \& $A B Q$, ICT

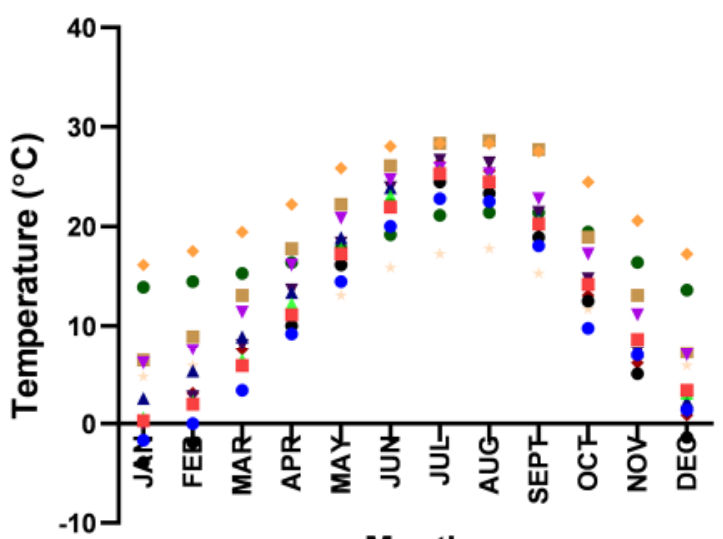

Month

Figure 3 Average monthly precipitation (left) and average monthly temperatures (right) for each city

Table 2 Current irrigation periods based on average monthly temperatures, average evapotranspiration (ET) value ranges (mm/day) (IWMI, 2018), and utility rates for all cities investigated within this study.

\begin{tabular}{|c|c|c|c|c|c|c|}
\hline \multirow{3}{*}{$\begin{array}{c}\text { EPA } \\
\text { Region }\end{array}$} & \multirow{3}{*}{ City, State (Abbrev.) } & \multirow{3}{*}{$\begin{array}{c}\text { Irrigation } \\
\text { Periods } \\
\text { (US CD, } \\
\text { 2018) }\end{array}$} & \multirow{2}{*}{$\begin{array}{c}\text { ET Range } \\
\text { (IWMI, 2018) }\end{array}$} & \multicolumn{2}{|c|}{ Utility Rates } & \multirow{2}{*}{$\begin{array}{c}\begin{array}{c}\text { Electricity } \\
\text { Price }\end{array} \\
(\mathrm{EIA}, 2018) \\
\end{array}$} \\
\hline & & & & Potable Water & Sewage & \\
\hline & & & $\mathrm{mm} /$ day & $\$ / \mathrm{m}^{3}$ & $\$ / \mathrm{m}^{3}$ & Cents/kWh \\
\hline 1 & Boston, MA (BOS) & $\begin{array}{c}\text { June- } \\
\text { September }\end{array}$ & $5.14-1.07$ & $\begin{array}{l}2.19 \text { (Boston, } \\
2016)\end{array}$ & $\begin{array}{l}2.97 \text { (Boston, } \\
2016)\end{array}$ & 19.94 \\
\hline 2 & $\begin{array}{l}\text { New York, NY (NYC) } \\
\text { (City of New York, 2018) }\end{array}$ & $\begin{array}{c}\text { May- } \\
\text { September }\end{array}$ & $5.67-1.21$ & $\begin{array}{c}1.36 \text { (City of } \\
\text { New York, } \\
2018)\end{array}$ & $\begin{array}{c}3.53 \\
\text { (City of New } \\
\text { York, 2018) }\end{array}$ & 18.59 \\
\hline 3 & Philadelphia, PA (PHIL) & $\begin{array}{c}\text { May- } \\
\text { September }\end{array}$ & $5.37-1.13$ & $\begin{array}{c}1.02 \\
\text { (Philadelphia, } \\
\text { 2016) }\end{array}$ & $\begin{array}{c}1.16 \\
\text { (Philadelphia, } \\
\text { 2016) }\end{array}$ & 14.41 \\
\hline
\end{tabular}




\begin{tabular}{|c|c|c|c|c|c|c|}
\hline & Atlanta, GA (ATL) & $\begin{array}{l}\text { April- } \\
\text { October }\end{array}$ & $5.43-1.56$ & $\begin{array}{c}2.20 \text { (City of } \\
\text { Atlanta, 2016) }\end{array}$ & $\begin{array}{c}5.60(\text { City of } \\
\text { Atlanta, 2016) }\end{array}$ & 12.74 \\
\hline 4 & Tampa, FL (TPA) & All Year & $5.77-2.37$ & $\begin{array}{c}2.40 \text { (City of } \\
\text { Tampa Florida, } \\
\text { 2011) }\end{array}$ & $\begin{array}{c}2.10 \text { (City of } \\
\text { Tampa Florida, } \\
\text { 2011) }\end{array}$ & 11.86 \\
\hline 5 & Chicago, IL (CHI) & $\begin{array}{c}\text { May- } \\
\text { September }\end{array}$ & $5.42-0.72$ & $\begin{array}{c}1.04 \text { (Chicago, } \\
2016)\end{array}$ & $\begin{array}{c}1.04 \text { (Chicago, } \\
2016)\end{array}$ & 12.59 \\
\hline & Dallas, TX (DAL) & $\begin{array}{l}\text { April- } \\
\text { October }\end{array}$ & $7.51-1.86$ & $\begin{array}{l}1.94 \text { (Dallas, } \\
2016)\end{array}$ & $\begin{array}{l}1.20 \text { (Dallas, } \\
2016)\end{array}$ & 11.11 \\
\hline 6 & Albuquerque, NM (ABQ) & $\begin{array}{c}\text { May- } \\
\text { September }\end{array}$ & $8.90-1.63$ & $\begin{array}{c}0.48 \\
\text { (Albuquerque, } \\
2016 \text { ) } \\
\end{array}$ & $\begin{array}{c}0.61 \\
\text { (Albuquerque, } \\
\text { 2016) } \\
\end{array}$ & 12.72 \\
\hline 7 & Wichita, KS (ICT) & $\begin{array}{c}\text { May- } \\
\text { September }\end{array}$ & $7.44-1.15$ & $\begin{array}{l}2.37 \text { (Wichita, } \\
\text { 2017) }\end{array}$ & $\begin{array}{c}0.78 \text { (Wichita, } \\
\text { 2017) } \\
\end{array}$ & 13.62 \\
\hline 8 & $\begin{array}{l}\text { Salt Lake City, UT(SLC) } \\
\text { (City, 2016) }\end{array}$ & $\begin{array}{c}\text { May- } \\
\text { September }\end{array}$ & $8.60-0.80$ & $\begin{array}{c}0.72 \text { (City } \\
2016) \\
\end{array}$ & 0.78 (City, 2016) & 11.62 \\
\hline 9 & San Diego, CA (SD) & $\begin{array}{c}\text { April- } \\
\text { November }\end{array}$ & $4.70-2.18$ & $\begin{array}{c}2.70 \text { (City of } \\
\text { San Diego, } \\
2016)\end{array}$ & $\begin{array}{l}1.28 \text { (City of San } \\
\text { Diego, 2016) }\end{array}$ & 19.02 \\
\hline 10 & Seattle, WA (SEA) & June- August & $4.50-0.68$ & $\begin{array}{r}2.30 \text { (City of } \\
\text { Seattle, 2017) }\end{array}$ & $\begin{array}{r}4.20 \text { (City of } \\
\text { Seattle, 2017) }\end{array}$ & 9.85 \\
\hline
\end{tabular}

\subsection{Household types}

This study examined two different household types in order to investigate the feasibility of implementing these two decentralized water systems. The two types of households include a typical two-story single-family home and a typical two-story multi-family building. Characteristics of a typical single-family home and a typical multi-family home were summarized in Table 3. Household characteristics (i.e., number of tenants, roof size, etc.) were based on residential housing data from available datasets obtained from various real estate websites (Otet, 2016; Terrazas, 2014) and the U.S. Census Bureau (USCB, 2017).

Little information has been published about characteristics for multi-family housing. Lawn size and rooftop size data were obtained from various real estate websites (Kaufman, 1962; Otet, 2016). To determine the average number of tenants per multi-family building, further analysis was conducted using the city of Boston, MA as an average urbanized city. The total number of tenants were calculated by adding up tenants for all households located in the high-density 
housing neighborhoods, where more than one address was associated with a building, using data obtained from Ural et al. (2011). Number of tenants per household was then calculated by dividing the total number of tenants by the total number of households (Ural et al., 2011).

Table 3 Summary of household parameters that are defined in this study for single-family and multi-family homes in an urban environment.

\begin{tabular}{|lcc|}
\hline Variable & Single-family & Multi-family \\
\hline Roof Size $\left(\mathbf{m}^{\mathbf{2}}\right)$ & 116 (Silva et al, 2015) & 427 (Otet, 2016) \\
\hline Lawn Size $\left.\mathbf{( m}^{\mathbf{2}}\right)$ & $526($ NAHB, 2015) & 162 (Kaufman, 1962) \\
\hline Number of Tenants per Building & 3 (Terrazas, 2014) & 15 (Ural et al., 2011; USCB, 2017) \\
\hline Building Height $\mathbf{( m )}$ & 5 (EPA, 2018) & 5 (EPA, 2018) \\
\hline
\end{tabular}

\subsection{Monte Carlo Analysis}

We conducted both a Monte Carlo analysis to investigate the uncertainties associated with the modelled results. The Monte Carlo analysis tests the possible behavioral boundaries of a model when multiple variables change simultaneously. The Vensim software used in this study allows automatic sampling of constants over a range of pre-defined values. The Latin Hypercube sampling method was used in this study, which enables faster sensitivity testing on large models. In this analysis, all constants within the multi-family house model were allowed to vary between $+/-20 \%$ of their base value, except for the discount rate, to capture the $50 \%, 75 \%, 95 \%$ and $100 \%$ likelihood of the modelled RWH and GWR net economic savings over the 10-year simulation period (Table 4). The test range of the discount rate was set to be between $0 \%$ and $0.016 \%$ per day, which gives an annual discount rate of roughly $0 \%$ to $6 \%$. The Monte Carlo analysis was repeated for 200 times with Boston as the sample city. 
Table 4 Variables tested during the Monte Carlo analysis for the city of Boston for both RWH and GWR.

\begin{tabular}{|c|c|c|}
\hline Variable & Base Value & Test Range \\
\hline Building height (m) & 5.0 & {$[4.0,6.0]$} \\
\hline Energy fee (\$/kWh) (EIA, 2018) & 0.199 & {$[0.159,0.239]$} \\
\hline Irrigation efficiency & 0.75 & {$[0.600,0.900]$} \\
\hline Lawn size $\left(\mathbf{m}^{2}\right)$ & 152 & {$[122,182]$} \\
\hline Flushing water demand (m3/person/day) & 0.072 & {$[0.057,0.086]$} \\
\hline Number of loads per day $\left(\mathrm{m}^{3} /\right.$ person/day $)$ & 0.32 & {$[0.256,0.384]$} \\
\hline Laundry volume per day ( $\mathrm{m}^{3} /$ person/day) & 0.056 & {$[0.045,0.068]$} \\
\hline Shower volume per day (m³/person/day) & 0.065 & {$[0.052,0.078]$} \\
\hline Sink volume per day (m $3 /$ person/day) & 0.022 & {$[0.018,0.027]$} \\
\hline Pump Efficiency & 0.5 & {$[0.400,0.600]$} \\
\hline Roof Area $\left(\mathrm{m}^{3}\right)$ & 427 & {$[342,512]$} \\
\hline Potable Water fee $\left(\$ / \mathbf{m}^{3}\right)$ & 2.19 & {$[1.75,2.63]$} \\
\hline Wastewater fee $\left(\left(\$ / \mathbf{m}^{3}\right)\right.$ & 2.97 & {$[2.38,3.56]$} \\
\hline Number of Tenants & 15 & {$[12,18]$} \\
\hline Runoff Coefficient & 0.8 & {$[0.640,0.960]$} \\
\hline Discount Rate & $0.008 \%$ & {$[0.000 \%, 0.016 \%]$} \\
\hline
\end{tabular}

\section{Results and Discussion}

\subsection{Payback Period}

Error! Reference source not found.Figure 5 shows results for the payback time of each technology investigated under different tank sizes in the 12 testbed cities. Cities not shown in Figure 5 indicate installation of RWH or GWR in these cities will never be paid back under the modelled conditions. 
GWR Payback Period for Single-family Housing

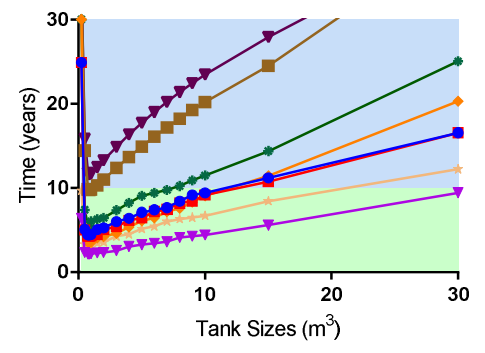

GWR Payback Period for Multi-family Housing

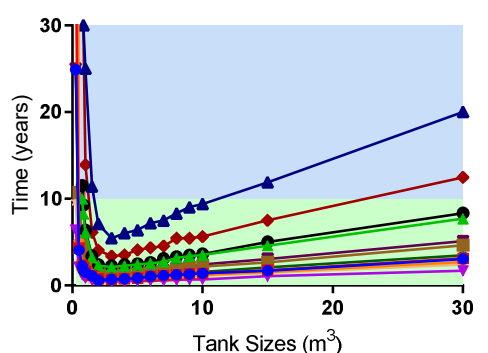

$\rightarrow \mathrm{BOS} \rightarrow \mathrm{NYC} \rightarrow \mathrm{PHIL} \rightarrow \mathrm{ATL} \rightarrow \mathrm{TPA} \rightarrow \mathrm{CHI}$

$\rightarrow \mathrm{DAL} \nrightarrow \mathrm{ABQ} \rightarrow \mathrm{ICT} \rightarrow \mathrm{SLC} \bullet \mathrm{SD} \leftarrow \mathrm{SEA}$
RWH Payback Period for Single-family Housing

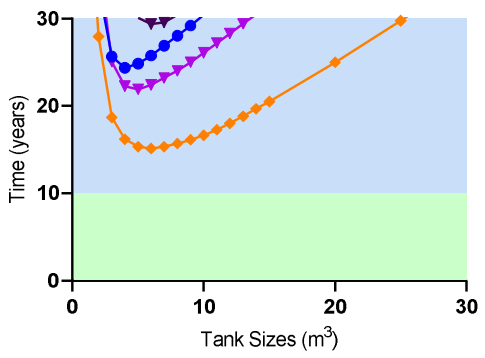

RWH Payback Period for Multi-family Housing

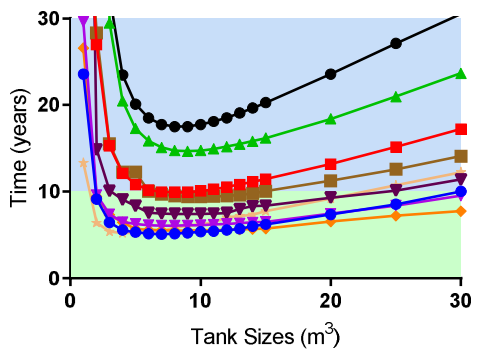

\section{AT}

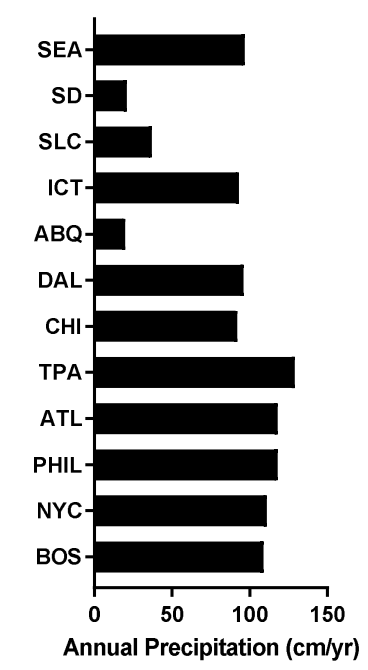

Figure 5 Payback period for all cities investigated. Shows the differences between each city, GWR and RWH, and single- and multi-family homes. The bar graph (far right) shows the total amount of precipitation received each year in the various cities. Cities in green area, are able to be paid back within the 10-year period. Cities in the blue area, do not achieve payback in the 10year period, but do within a 30-year period

When the GWR system is installed in a typical single-family house, Atlanta and Seattle generally have the shortest payback time (2-3 years) with a tank size of $0.5-2.0 \mathrm{~m}^{3}$, while Tampa, Boston, New York, and San Diego all have payback periods between 3-5 years at tank sizes 0.75-1.0 $\mathrm{m}^{3}$. Dallas and Wichita generally have a longer payback time, between 9-12 years with a tank size range from of $0.75-1.0 \mathrm{~m}^{3}$. Salt Lake City, Albuquerque, Chicago, and Philadelphia, however, will never be paid back within a 30-year timeframe regardless of system size. Payback time of 
the GWR systems is dominated by the potable water and wastewater fees within a city. The lower the potable water and wastewater fees are for a city, the longer the payback period will be. Local climate and irrigation demand, however, do not play a significant role in the payback time of the GWR systems. An optimal tank size between $0.75-0.85 \mathrm{~m}^{3}$ was found in all studied cities for this typical single-family housing. A similar concave pattern was observed between tank size and the payback time across all cities.

All cities were able to achieve a payback time when the GWR system is installed in a typical multi-family housing. This is because there are more tenants utilizing the system, more tenants increasing the influent volume for the GWR storage, and there is less of an overall demand because of the smaller lawn size compared to single-family housing. In this case, all cities will have a return of investment within ten years. Atlanta, Seattle, Boston, Tampa, New York City, and San Diego have the shortest payback time of less than one year, while Philadelphia, Chicago, Salt Lake City, and Albuquerque have longer payback times between 2 and 6 years. For all the cities, the optimum tanks sizes for payback is $2-3 \mathrm{~m}^{3}$. Household size has a relatively significant impact on the GWR's return of investment because water generation is a limiting factor given the demand of non-potable water (toilet flushing particularly). Yields of multi-family housing are around 2-3 times those of the single-family housing, which has led to much more significant annual savings from the multi-family housing and hence shorter payback periods. An optimal tank size of 2-3 $\mathrm{m}^{3}$ was found in all studied cities for this typical multi-family housing.

When the RWH system is installed in a typical single-family housing Tampa, Atlanta, and Boston cities generally have the shortest payback time, despite all of them exceeding the 10 -year 
simulation period ( 15 to 24 years) with tank sizes ranging from 4-6 $\mathrm{m}^{3}$. This is a combined effect of precipitation pattens and potable water fees. These cities tend to have more frequent precipitation events with relatively constant intensity and higher potable water fees. Wichita and Seattle have longer payback times ( 30 to 42 years) with tank sizes ranging from 4-6 $\mathrm{m}^{3}$. New York, Philadelphia, Dallas, San Diego, Salt Lake City, Albuquerque, and Chicago, however, will never be paid back regardless of system size.

When the RWH system is installed in a typical multi-family housing Boston, Tampa, and Seattle generally have the shortest payback time (5-6 years). Atlanta, Wichita, Dallas and New York had payback periods occur between 7 and 10 years. Philadelphia and Chicago do reach payback, but they go beyond the 10-year period (15 to 17 years). The increase in number of cities achieving payback is because the collected inflow is increased due to a bigger roof area. An optimal tank size of $5-10 \mathrm{~m}^{3}$ was found in the studied cities for this typical multi-family housing. This is because the amount of non-potable water available allows increased usability of the system itself. However, when the tank size and cost of the initial investment further increases, the payback time will increase again because the daily savings will need to accumulate for a longer period of time in order to offset the cost, if at all.

Overall, the GWR system is the most suitable for Atlanta, Tampa, and Seattle out of the studied cities based on payback time, while the RWH system is most suitable for Boston, Atlanta, and Tampa out of the studied cities. 


\subsection{Demand Met}

Figure 7 shows the results for the demand met for each technology investigated and each household size considered. The highest percent demand met ranges from $50 \%$ to $70 \%$ for RWH systems and $70 \%$ to $90 \%$ for GWR systems across the twelve cities. GWR system generally provides a higher percent demand met than the RWH system. This is because GWR has a reliable source of influent being generated daily, RWH is dependent on the amount and timing of precipitation being generated.

When comparing cities, Seattle and Boston result in the highest percent demand met and Tampa and San Diego have the lowest when the GWR system is utilized. When the RWH system is utilized, Seattle, Boston, and New York City have the highest percent demand met while Albuquerque, Tampa, and San Diego have the lowest. The demand met of GWR systems is primarily determined by the system's capability to meet the irrigation demand. The demand met of RWH systems is primarily determined by the availability of rainwater supply as well as the varying irrigation demand and climate characteristics. Those cities that have longer irrigation periods obtain a smaller demand met percentage, while cities with shorter irrigation periods typically have higher demand met percentages.

RWH achieved a higher demand met percentage for single-family households compared to multi-family households, while GWR stayed at similar percentages between both multi- and single- family housing. This could be because the water collection for GWR is proportional to the usage for both multi- and single-family housing. RWH is not meeting the demand for multifamily housing because there are too many people using the technology and the collection area 
of the roof and the amount of rainfall that is able to be collected does not correlate to the total number of occupants.

The tank size that achieves the smallest payback time does not align with the tank size that maximizes percent demand met. When the tank size is optimized for payback time, the percent demand met is generally $10 \%$ lower than the highest achievable demand met. With the highest achievable demand met, payback time takes generally 2-4 times longer than the optimized tank size for payback. This indicates a tradeoff between sizing for minimized payback time or maximized demand met. In previous studies, people have prioritized socio-economic drivers, such as payback, in their decision of implementing RWH or GWR (Mankad \& Tapsuwan, 2011; Wang \& Zimmerman, 2015). In cities where there is some overlap in demand met and quick payback, such as Boston, Atlanta, and Seattle, the decision to implement one of the decentralized options is easier to make. For cities where payback and demand met are opposite, such as Tampa and New York, maximizing payback may be the deciding factor on the household-scale. But in other areas where water scarcity and reliability are major concerns, meeting daily demand should be the top priority. To help alleviate increased demand, policies encouraging water conservation should be implemented to help promote adoption of GWR and RWH. As more decentralized systems are put in place in smaller scale buildings, the potential for financial assistance or resources in urban development and planning may increase (Leigh \& Lee, 2019). 
GWR Demand Met for Single-family Housing

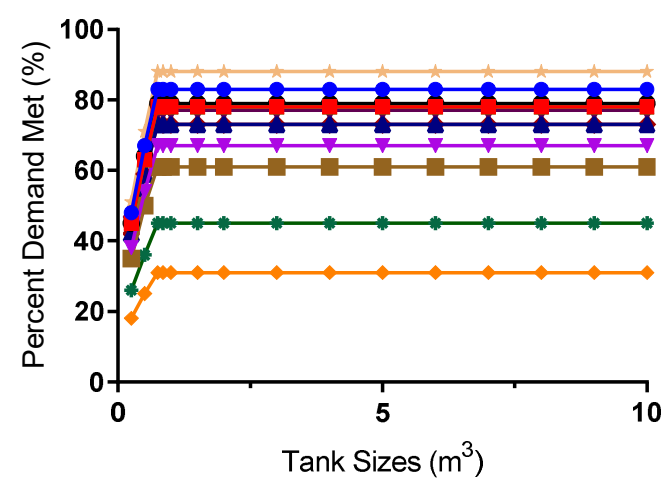

GWR Demand Met for Multi-family Housing

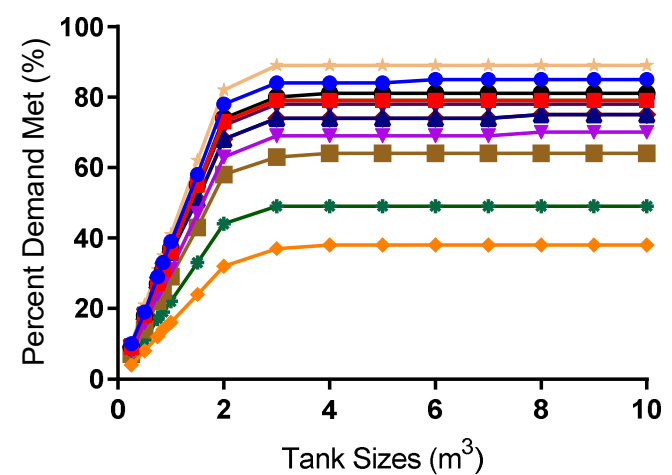

RWH Demand Met for Single-family Housing

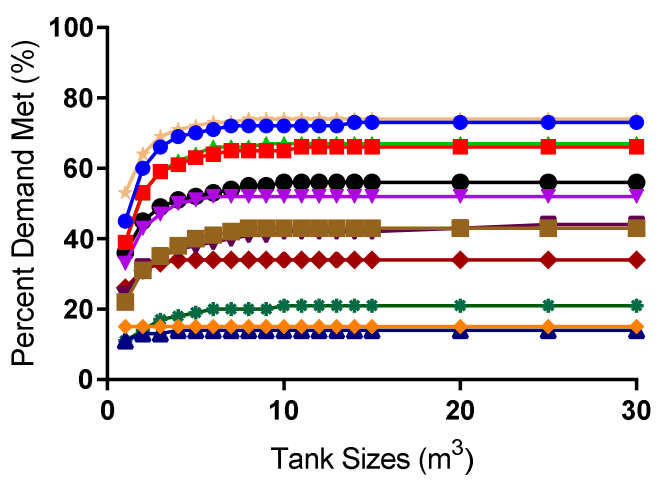

RWH Demand Met for Multi-family Housing

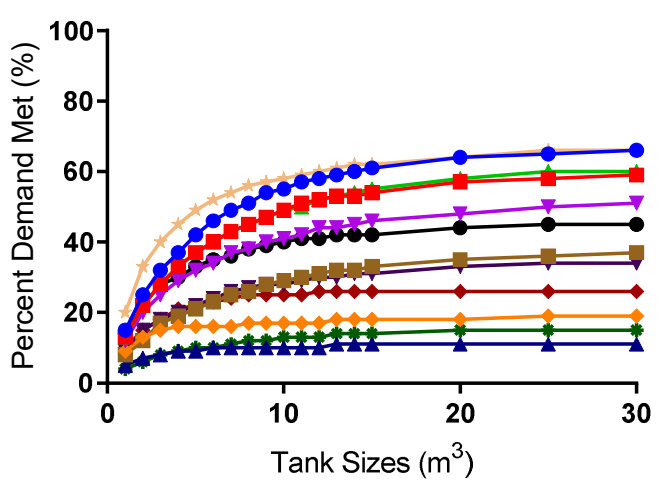

$\rightarrow \mathrm{BOS} \rightarrow \mathrm{NYC} \leftarrow \mathrm{PHIL} \rightarrow \mathrm{ATL} \rightarrow \mathrm{TPA} \rightarrow \mathrm{CHI}$

$\rightarrow \mathrm{DAL} \leftarrow \mathrm{ABQ} \rightarrow \mathrm{ICT} \leftrightarrow \mathrm{SLC} * \mathrm{SD} \leftarrow \mathrm{SEA}$

Figure 7 Demand met percentages for all cities investigated. Shows the differences between each city, GWR and RWH, and single- and multi-family homes.

\subsection{Monte Carlo and Sensitivity Analysis}

The 50\%, 75\%, 95\% and 100\% likelihood of the RWH and GWR economic savings over the 10 year simulation period in response to changes in tested variables are shown in Figure 8 and Figure 9. The results show that RWH economic savings over ten years are at a range of $\$(-400)$ $\$ 3,900$ with $100 \%$ confidence, and a range of $\$ 900-\$ 2,200$ with $50 \%$ confidence. The analysis shows that uncertainties in the values of the model variables are not likely to result in the 
collapse of economic saving for RWH, except for the lowest $5 \%$ of the simulations, because $95 \%$ of the simulations reach payback within the 10-year period. However, the specific time in which it reaches payback varies within the 10-years' time frame.

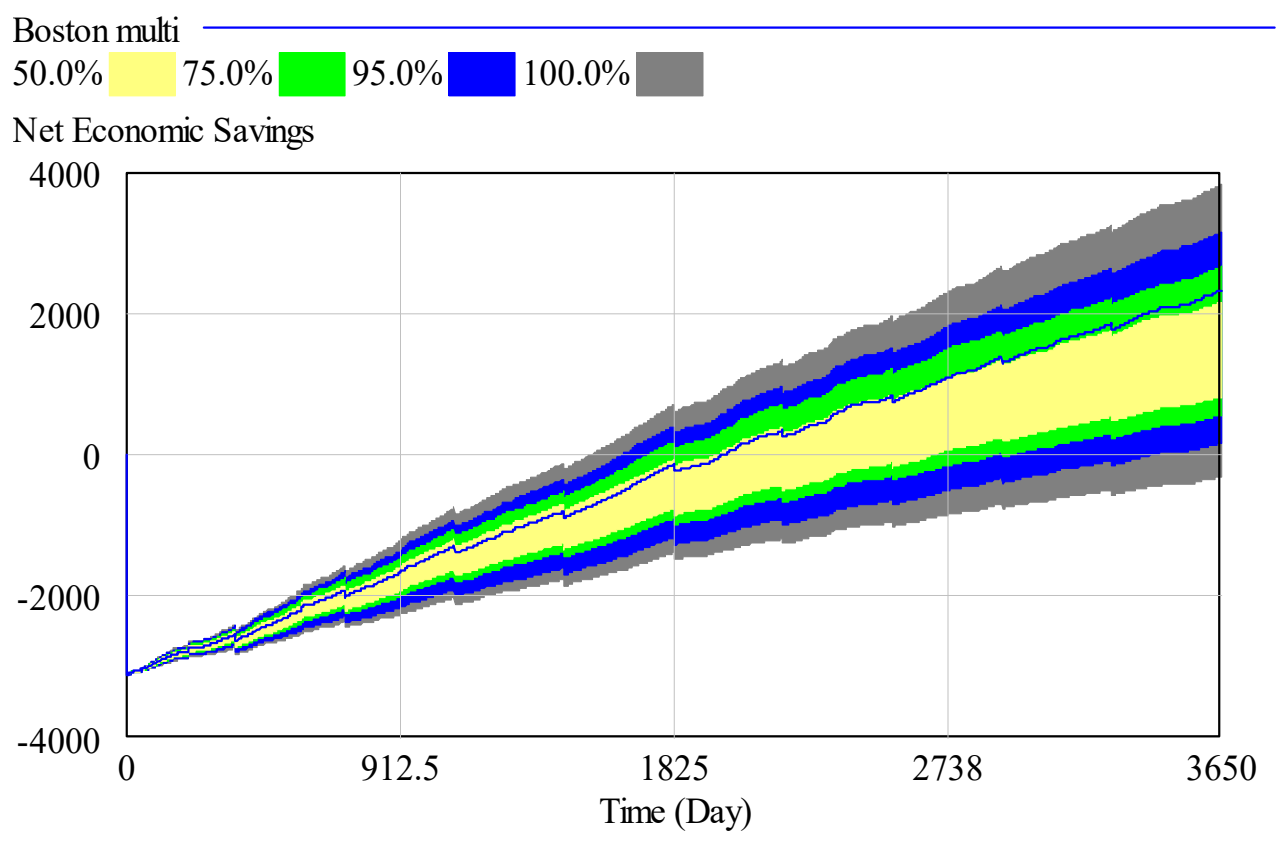

Figure 8 Monte Carlo simulation of RWH model at $11 \mathrm{~m}^{3}$ tank size for the city of Boston, MA over a 10-year period for a multi-family household.

GWR economic savings over 10 years are at a range of $\$ 8,000-\$ 16,750$ with $100 \%$ confidence, and a range of $\$ 12,000-\$ 14,500$ with $50 \%$ confidence. The analysis shows that uncertainties in the values of the model variables are not likely to result in the collapse of economic savings because $100 \%$ of the simulations reach payback within the 10 -year period. However, the specific time in which it reaches payback varies within a years' time frame. 


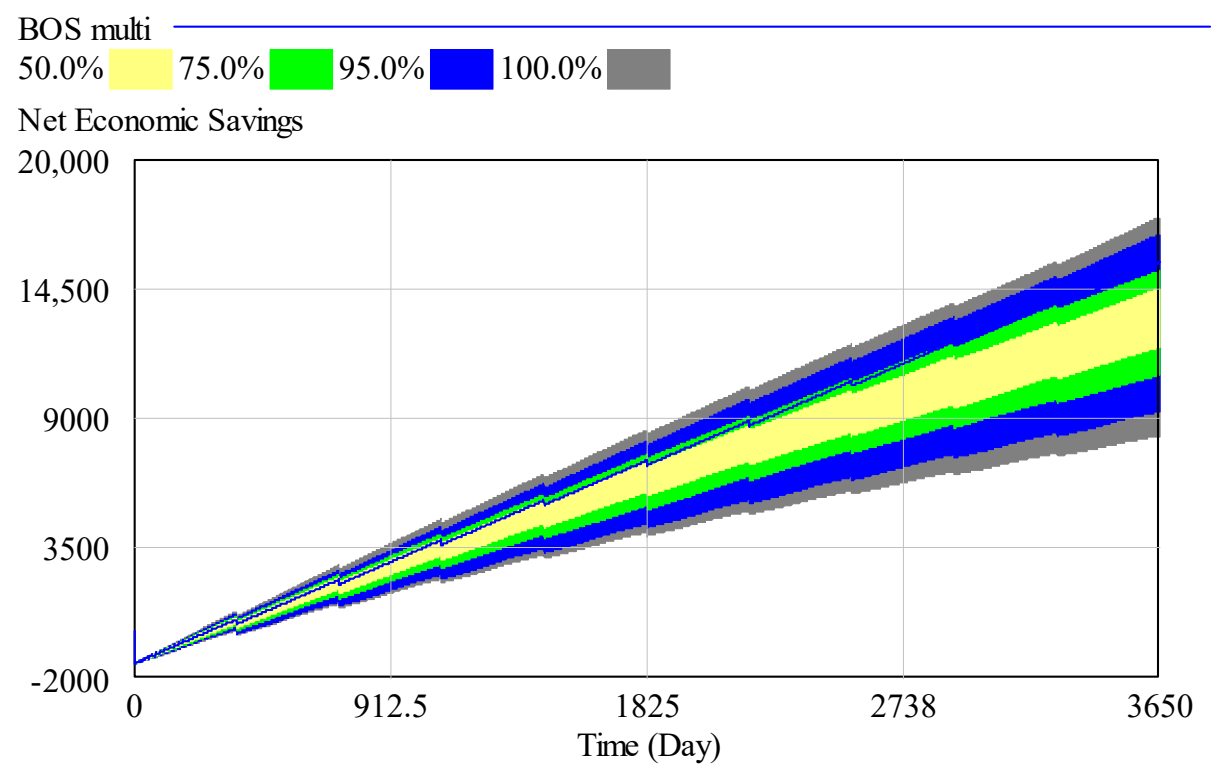

Figure 9 Monte Carlo simulation of GWR model at $2 \mathrm{~m}^{3}$ tank size for the city of Boston, MA over a 10-year period for a multi-family household.

\section{Conclusions}

This study conducted a life cycle cost assessment integrated with dynamic modeling to investigate whether GWR or RWH have appropriate payback and demand met capabilities in two different household types across 12 US cities. We found that for GWR, cities had optimum tank sizes of 2-3 $\mathrm{m}^{3}$ for multi-family housing and $0.75-0.85 \mathrm{~m}^{3}$ for single-family housing. Payback varied between the cities investigated for GWR, however Atlanta, Tampa, and Seattle are most suitable for GWR. For RWH, optimized tank sizes range from 5-10 $\mathrm{m}^{3}$ for multi-family housing and 4-6 $\mathrm{m}^{3}$ for single-family housing. Payback varied between cities and many cities were not able to achieve payback for RWH. Investigation for RWH concluded that Boston, Tampa, and Atlanta were most suitable for installation in terms of payback. Demand met for GWR ranged from 70\%-90\%, while RWH ranged from 50\%-70\% across all cities. For the demand met metric, Seattle and Boston achieved the highest percentages. Boston and Tampa 
achieved the highest percentages for RWH demand met. Overall, Boston, Seattle, and Atlanta performed the best for both GWR and RWH, single-family and mulit-family, and payback and demand met.

Future studies should focus on the improvement of available datasets pertaining to household/city characteristics to further improve confidence on outcomes for payback and demand met. This study applied generalized city characteristics to each city investigate to identify key variable influences. Future studies should analyze the U.S. cities in this study to included city-specific characteristics that are more appropriate to the city itself to determine if other variables have an impact. Future studies should also consider inclusion of different technological approaches for GWR and RWH for water treatment and how water quality from reuse effects payback and environmental viability. Additionally, the effect of climate change on decentralized system should be investigated and how socio-economic factors effect public perception.

\section{Acknowledgement}

This work would not be possible without the support of the National Science Foundation under a CRISP Type I Award (\#BCS-1638334) and a CBET Award (\#CBET-1706143) and Dr. Kyle Kwiatkowski for providing feedback and guidance. Any Opinions, findings, and conclusions or recommendations expressed in this material are those of the authors and do not necessarily reflect the views of the National Science Foundation. 


\section{Bibliography}

Abbasi, T., \& Abbasi, S. A. (2011). Sources of pollution in rooftop rainwater harvesting systems and their control. Critical Reviews in Environmental Science and Technology, 41(23), 2097-2167. https://doi.org/10.1080/10643389.2010.497438

Albuquerque, C. of. (2016). Welcome to the Albuquerque Water Utility Authority. http://www.abcwua.org/

Boston, C. of. (2016). Massachusetts Document Repository. https://docs.digital.mass.gov/dataset/massgis-data-impervious-surface-2005

Brown, T. C., Mahat, V., \& Ramirez, J. A. (2019). Adaptation to Future Water Shortages in the United States Caused by Population Growth and Climate Change. Earth's Future, 7(3), 219-234. https://doi.org/10.1029/2018EF001091

Campisano, A., Butler, D., Ward, S., Burns, M. J., Friedler, E., DeBusk, K., Fisher-Jeffes, L. N., Ghisi, E., Rahman, A., Furumai, H., \& Han, M. (2017). Urban rainwater harvesting systems: Research, implementation and future perspectives. In Water Research (Vol. 115, pp. 195-209). Elsevier Ltd. https://doi.org/10.1016/j.watres.2017.02.056

Chicago, C. of. (2016). City of Chicago :: Utility Billing \& Customer Service. https://www.chicago.gov/city/en/depts/fin/provdrs/utility_billing.html

City, C. of S. L. (2016). Current Rates | Public Utilities. https://www.slc.gov/utilities/pay-mybill/current-rates/

City of Atlanta. (2016). Water and Sewer Bill Rates. Department of Watershed Management. https://rive.google.com/file/d/1KdbW1uTS5iHjwtp4Vr3dYGyvy4v7DTTm/view

City of New York. (2018). NYC Resources | Categories | City of New York. https://www1.nyc.gov/nyc-resources/categories.page 
City of San Diego. (2016). City of San Diego Official Website. https://www.sandiego.gov/

City of Seattle. (2017). Drainage Rate Schedule - Utilities | seattle.gov.

http://www.seattle.gov/utilities/businesses-and-key-accounts/drainage-and-sewer/drainagerates/rate-schedule

City of Tampa Florida. (2011). Utilities Information | City of Tampa.

https://www.tampagov.net/info/utilities

CTCN. (2018). Rainwater harvesting | Climate Technology Centre \& Network. https://www.ctcn.org/technologies/rainwater-harvesting

Dallas, C. of. (2016). Welcome to the City of Dallas, Texas. https://dallascityhall.com/Pages/default.aspx

Das, O., Bera, P., \& Moulick, S. (2015). WATER CONSERVATION ASPECTS OF GREEN BUILDINGS. International Journal of Research in Engineering and Technology, 75-79. https://www.researchgate.net/publication/310611986_WATER_CONSERVATION_ASPE CTS_OF_GREEN_BUILDINGS

Despins, C., Farahbakhsh, K., \& Leidl, C. (2009). Assessment of rainwater quality from rainwater harvesting systems in Ontario, Canada. Journal of Water Supply: Research and Technology - AQUA, 58(2), 117-134. https://doi.org/10.2166/aqua.2009.013

EA. (2010). Harvesting rainwater for domestic uses: an information guide. www.environmentagency.gov.uk

EIA. (2018). Electric Power Monthly. U.S. Energy Information Administration. https://www.eia.gov/electricity/monthly/epm_table_grapher.php?t=epmt_5_6_a

EPA. (2016, September 16). Federal Register :: Draft National Water Reuse Action Plan. Environmental Protection Agency. 
https://www.federalregister.gov/documents/2019/09/16/2019-19984/draft-national-waterreuse-action-plan

EPA. (2018). Water Budget Tool | WaterSense | US EPA. https://www.epa.gov/watersense/water-budget-tool

Eriksson, E. H. (2002). Potential and problems related to reuse of water in households. Environment \& Resources, Technical University of Denmark, DTU.

Fewkes, A., \& Butler, D. (2000). Simulating the performance of rainwater collection and reuse systems using behavioural models. Building Services Engineering Research and Technology, 21(2), 99-106. https://doi.org/10.1177/014362440002100204

Fewtrell, L., \& Kay, D. (2007). Microbial quality of rainwater supplies in developed countries: a review. Urban Water Journal, 4(4), 253-260. https://doi.org/10.1080/15730620701526097

Ford, A. (2010). Modeling the environment (Second Edition). Island Press. https://unh.primo.exlibrisgroup.com/discovery/fulldisplay?docid=proquest16204616\&conte $\mathrm{xt}=\mathrm{PC} \& \mathrm{vid}=01 \mathrm{USNH} \_\mathrm{UNH}: \mathrm{MAIN} \&$ lang $=$ en\&search_scope $=$ MyInst_and_CI\&adaptor $=\operatorname{Pr}$ imo Central\&tab=Everything\&query=any,contains, on site greywater treatment and reuse in,AND\&query $=$ any,contains, friedler,AND\&mode $=$ advanced\&offset $=0$

Forrester, G., Burgess, C., \& Hale, T. C. (2018). Bermudagrass Yearly Maintenance Program . Home \& Garden Information Center: Clemson Cooperative Extension. https://hgic.clemson.edu/factsheet/bermudagrass-maintenance-calendar/

Friedler, E. (2008). The water saving potential and the socio-economic feasibility of greywater reuse within the urban sector - Israel as a case study. International Journal of Environmental Studies, 65(1), 57-69. https://doi.org/10.1080/00207230701846697

Friedler, Eran, \& Hadari, M. (2006). Economic feasibility of on-site greywater reuse in multi- 
storey buildings. Desalination, 190(1-3), 221-234.

https://doi.org/10.1016/j.desal.2005.10.007

GhaffarianHoseini, A., Tookey, J., GhaffarianHoseini, A., Yusoff, S. M., \& Hassan, N. B. (2016). State of the art of rainwater harvesting systems towards promoting green built environments: a review. Desalination and Water Treatment, 57(1), 95-104.

https://doi.org/10.1080/19443994.2015.1021097

Goatley Jr., M. (2015). Fall Lawn Care . Virginia Cooperative Extension, 430(520), 1-6. http://digitalpubs.ext.vt.edu/vcedigitalpubs/1638186788765552/MobilePagedReplica.action $? \mathrm{pm}=2 \&$ folio $=1 \# \mathrm{pg} 1$

GWA. (n.d.). Greywater Reuse. Greywater Action. Retrieved March 2, 2020, from https://greywateraction.org/greywater-reuse/

Hameeteman, E., Jadot, S., Hameeteman, E., \& Jadot, S. (2013). Concepts and Context of the Global Water Institute: Approach to Reintegration of Ex-Combatants through Water Strategies The authors would like to thank Magda Kocianova and Natalia Madryga for their helpful comments. Approach to Reintegration of Ex-Combatants through Water Strategies.

Hamel, P., \& Fletcher, T. D. (2014). The impact of stormwater source-control strategies on the (low) flow regime of urban catchments. Water Science and Technology, 69(4), 739-745. https://doi.org/10.2166/wst.2013.772

Hashim, H., Hudzori, A., Yusop, Z., \& Ho, W. S. (2013). Simulation based programming for optimization of large-scale rainwater harvesting system: Malaysia case study. Resources, Conservation and Recycling, 80(1), 1-9. https://doi.org/10.1016/j.resconrec.2013.05.001 HWW. (2018). Water Use, Efficiency and Savings - Indoor Use. Home Water Works: Alliance 
for Water Efficiency. https://www.home-water-works.org/indoor-use

Ilemobade, A. A., Olanrewaju, O. O., \& Griffioen, M. L. (2013). Greywater reuse for toilet flushing at a university academic and residential building. Water SA : WISA 2012 Conference Special Edition, 39(3), 351-360.

IWMI. (2018). International Water Management Institute (IWMI) : A water-secure world. https://www.iwmi.cgiar.org/

Jefferson, B., Laine, A., Le Clech, P., Diaper, C., Carter, B., \& Judd, S. (2000). Technologies for domestic wastewater recycling. Environmental Protection Bulletin, 64(4), 8-14. https://doi.org/10.1016/s1462-0758(00)00030-3

Jenkins, D. . P. F. . M. E. . K. S. J. . V. R. (1978). Feasibility of Rainwater Collection Systems in California. California Water Resources Center, University of California, 173.

Jeong, H., Broesicke, O. A., Drew, B., \& Crittenden, J. C. (2018). Life cycle assessment of small-scale greywater reclamation systems combined with conventional centralized water systems for the City of Atlanta, Georgia. Journal of Cleaner Production, 174, 333-342. https://doi.org/10.1016/j.jclepro.2017.10.193

Kaufman, J. (1962). Illustrating the Zoning Ordinance. American Society of Planning Officials. https://www.planning.org/pas/reports/report165.htm

Lam, C. M., Leng, L., Chen, P. C., Lee, P. H., \& Hsu, S. C. (2017). Eco-efficiency analysis of non-potable water systems in domestic buildings. Applied Energy, 202, 293-307. https://doi.org/10.1016/j.apenergy.2017.05.095

Lawns. (2018). Lawncare Advice, Maintenance, and Care. http://www.american-lawns.com/ Leigh, N., \& Lee, H. (2019). Sustainable and Resilient Urban Water Systems: The Role of Decentralization and Planning. Sustainability, 11(3), 918. 
https://doi.org/10.3390/su11030918

Leong, J. Y. C., Oh, K. S., Poh, P. E., \& Chong, M. N. (2017). Prospects of hybrid rainwatergreywater decentralised system for water recycling and reuse: A review. Journal of Cleaner Production, 142, 3014-3027. https://doi.org/10.1016/j.jclepro.2016.10.167

Lesjean, B., \& Gnirss, R. (2006). Grey water treatment with a membrane bioreactor operated at low SRT and low HRT. Desalination, 199(1-3), 432-434. https://doi.org/10.1016/j.desal.2006.03.204

Li, F., Wichmann, K., \& Otterpohl, R. (2009). Review of the technological approaches for grey water treatment and reuses. In Science of the Total Environment (Vol. 407, Issue 11, pp. 3439-3449). Elsevier B.V. https://doi.org/10.1016/j.scitotenv.2009.02.004

Liu, R., Huang, X., Chen, L., Wen, X., \& Qian, Y. (2005). Operational performance of a submerged membrane bioreactor for reclamation of bath wastewater. Process Biochemistry, 40(1), 125-130. https://doi.org/10.1016/j.procbio.2003.11.038

Maeda, M., Nakada, K., Kawamoto, K., \& Ikeda, M. (1996). Area-wide use of reclaimed water in Tokyo, Japan. Water Science and Technology, 33(10-11), 51-57. https://doi.org/10.1016/0273-1223(96)00406-4

Mankad, A., \& Tapsuwan, S. (2011). Review of socio-economic drivers of community acceptance and adoption of decentralised water systems. In Journal of Environmental Management (Vol. 92, Issue 3, pp. 380-391). Academic Press. https://doi.org/10.1016/j.jenvman.2010.10.037

Marinoski, A. K., Rupp, R. F., \& Ghisi, E. (2018). Environmental benefit analysis of strategies for potable water savings in residential buildings. Journal of Environmental Management, 206, 28-39. https://doi.org/10.1016/j.jenvman.2017.10.004 
Marteleira, R., \& Niza, S. (2018). Does rainwater harvesting pay? Water-energy nexus assessment as a tool to achieve sustainability in water management. Journal of Water and Climate Change, 9(3), 480-489. https://doi.org/10.2166/wcc.2017.003

Memon, F. A., Butler, D., Han, W., Liu, S., Makropoulos, C., Avery, L. M., \& Pidou, M. (2005). Economic assessment tool for greywater recycling systems. Proceedings of the Institution of Civil Engineers: Engineering Sustainability, 158(3), 155-161. https://doi.org/10.1680/ensu.2005.158.3.155

Morales-Pinzón, T., Rieradevall, J., Gasol, C. M., \& Gabarrell, X. (2015). Modelling for economic cost and environmental analysis of rainwater harvesting systems. Journal of Cleaner Production, 87(C), 613-626. https://doi.org/10.1016/j.jclepro.2014.10.021

Murphy, J. A. (2001). Best Management Practices for Watering Lawns. Rutgers-Cook College Resource CenteR. https://njaes.rutgers.edu/pubs/publication.php?pid=fs555

Mwenge Kahinda, J., Taigbenu, A. E., Sejamoholo, B. B. P., Lillie, E. S. B., \& Boroto, R. J. (2009). A GIS-based decision support system for rainwater harvesting (RHADESS). Physics and Chemistry of the Earth, 34(13-16), 767-775. https://doi.org/10.1016/j.pce.2009.06.011

NAHB. (2015). Lots in 2015 are Smallest on Record | Eye On Housing. National Association of Home Builders. http://eyeonhousing.org/2016/07/lots-in-2015-are-smallest-on-record/

NESC. (2000). Decentralized Wastewater Treatment Systems”, Pipeline (Issue 11(4)). http://www.nesc.wvu.edu/pdf/WW/publications/pipline/PL_FA00.pdf

NOAA. (2018). National Oceanic and Atmospheric Administration | U.S. Department of Commerce. https://www.noaa.gov/

Nolde, E. (2000). Greywater reuse systems for toilet flushing in multi-storey buildings - over ten 
years experience in Berlin. Urban Water, 1(4), 275-284. https://doi.org/10.1016/s14620758(00)00023-6

Otet, A. (2016, June). Average Apartment Size in the US: Atlanta Has Largest Homes. RentCafe Blog. https://www.rentcafe.com/blog/rental-market/real-estate-news/us-apartment-size2016/

Otterpohl, R., Albold, A., \& Oldenburg, M. (1999). Source control in urban sanitation and waste management: Ten systems with reuse of resources. Water Science and Technology, 39(5), 153-160. https://doi.org/10.1016/S0273-1223(99)00097-9

Philadelphia, C. of. (2016). Attachment A Rates and Charges Philadelphia Water Department. https://www.phila.gov/water/PDF/RatesCharges_effective_7-1-2016.pdf

Rahman, A., Dbais, J., Mitchell, C., Ronaldson, P., \& Shrestha, S. (2007). Study of rainwater tanks as a source of alternative water supply in a multistorey residential building in Sydney Australia. Restoring Our Natural Habitat - Proceedings of the 2007 World Environmental and Water Resources Congress. https://doi.org/10.1061/40927(243)596

Rahman, A., Keane, J., \& Imteaz, M. A. (2012). Rainwater harvesting in Greater Sydney: Water savings, reliability and economic benefits. Resources, Conservation and Recycling, 61, 1621. https://doi.org/10.1016/j.resconrec.2011.12.002

Rain Harvest Systems. (2017). Above Ground Plastic Water Tanks . https://www.rainharvest.com/water-tanks-plastic/above-ground-tanks.asp

Roebuck, R. M., Oltean-Dumbrava, C., \& Tait, S. (2011). Whole life cost performance of domestic rainwater harvesting systems in the United Kingdom. Water and Environment Journal, 25(3), 355-365. https://doi.org/10.1111/j.1747-6593.2010.00230.x

Siegel, M. (2015). WATER TREATMENT IN RAINWATER HARVESTING SYSTEMS FOR 
POTABLE USE.

Silva, C. M., Sousa, V., \& Carvalho, N. V. (2015). Evaluation of rainwater harvesting in Portugal: Application to single-family residences. Resources, Conservation and Recycling, 94,21-34. https://doi.org/10.1016/j.resconrec.2014.11.004

Song, C., \& Mo, W. (2019). A temporal perspective to dam management: influence of dam life and threshold fishery conditions on the energy-fish tradeoff. Stochastic Environmental Research and Risk Assessment, 1-12. https://doi.org/10.1007/s00477-019-01726-7

Song, C., Omalley, A., Roy, S. G., Barber, B. L., Zydlewski, J., \& Mo, W. (2019). Managing dams for energy and fish tradeoffs: What does a win-win solution take? Science of the Total Environment, 669, 833-843. https://doi.org/10.1016/j.scitotenv.2019.03.042

SOW. (2018). Around the House - Save Our Water. Save Our Water. https://saveourwater.com/how-to-save-water/around-the-house/

Supplies, R. H. (2017). Tanks - Poly Water Tanks - Rainwater Storage Tanks - Page 1 - Rain Harvesting Supplies, Inc. https://rainharvestingsupplies.com/rainwater-storagetanks/?sort=featured\&page $=1$

SWRCB. (2011). Runoff Coefficient (C) Fact Sheet. http://water.me.vccs.edu/courses/CIV246/table2b.htm

Terrazas, A. (2014, September 30). New Home Construction Bulks Up: Denser and Bigger Zillow Research. U.S. Census Bureau. https://www.zillow.com/research/bigger-homessmaller-lots-sept-2015-10705/

UNDP. (2006). Human Development Report 2006 Beyond scarcity: Power, poverty and the global water crisis. http://hdr.undp.org

Ural, S., Hussain, E., \& Shan, J. (2011). Building population mapping with aerial imagery and 
GIS data. International Journal of Applied Earth Observation and Geoinformation, 13(6), 841-852. https://doi.org/10.1016/j.jag.2011.06.004

US CD. (2018). Climate United States - Monthly Averages. U.S. Climate Data. https://www.usclimatedata.com/

USCB. (2017). QuickFacts: Boston city, Massachusetts. U.S. Census Bureau. https://www.census.gov/quickfacts/fact/table/bostoncitymassachusetts/IPE120218

USGS. (2016). Water Use in the United States. United States Geological Survey. https://www.usgs.gov/mission-areas/water-resources/science/water-use-united-states?qtscience_center_objects $=0 \#$ qt-science_center_objects

Valentina Lazarova, Takashi Asano, A. B. and J. A. (2013). Milestones in Water Reuse.

Vieira, A. S., Beal, C. D., Ghisi, E., \& Stewart, R. A. (2014). Energy intensity of rainwater harvesting systems: A review. In Renewable and Sustainable Energy Reviews (Vol. 34, pp. 225-242). Elsevier Ltd. https://doi.org/10.1016/j.rser.2014.03.012

Vítková, E., Hromádka, V., \& Raclavský, J. (2014). Economic analysis of the greywater treatment project. An International Scientific Conference, 478-484. www.fce.vutbr.cz/ekr/PBE

Waltz, C., \& Landry, G. (2017). Lawn Care Calendar for Warm-Season Lawns. Pennington. https://www.pennington.com/all-products/grass-seed/resources/month-by-month-carecalendar-for-warm-season-lawns

Wang, R., \& Zimmerman, J. B. (2015). Economic and environmental assessment of office building rainwater harvesting systems in various U.S. Cities. Environmental Science and Technology, 49(3), 1768-1778. https://doi.org/10.1021/es5046887

Ward, S., Memon, F. A., \& Butler, D. (2012). Performance of a large building rainwater 
harvesting system. Water Research, 46(16), 5127-5134.

https://doi.org/10.1016/j.watres.2012.06.043

Wichita, C. of. (2017). Ordinance NO. 50-625.

https://www.wichita.gov/PWU/Pages/default.aspx

Willuweit, L., \& O’Sullivan, J. J. (2013). A decision support tool for sustainable planning of urban water systems: Presenting the dynamic urban water simulation model. Water Research, 47(20), 7206-7220.

WRF. (2018). BMP and LID Whole Life Cost Models: Version 2.0| The Water Research Foundation. Water Research Foundation. https://www.waterrf.org/research/projects/bmpand-lid-whole-life-cost-models-version-20

WWC. (2014). Water Crisis. World Water Council. https://www.worldwatercouncil.org/en/water-crisis 